\title{
PATOMAN SEBAGAI DESA KEBANGSAAN DI KABUPATEN BANYUWANGI
}

\author{
Bayu Indra Permana ${ }^{1}$, Agus Mursidi \\ ${ }^{1}$ Program Studi PPKn FKIP Universitas PGRI Banyuwangi \\ ${ }^{2}$ Program Studi Pendidikan Sejarah FKIP Universitas PGRI Banyuwangi \\ ${ }^{12}$ Email : bayundraper@gmail.com, agusmursidi78@yahoo.co.id
}

\begin{abstract}
Identification of the emergence of a nationality village in Patoman village needs to be done, this is done because Patoman village has the potential of various types of heterogeneous communities in terms of religion, culture or ethnicity. So it needs to be traced and further studies need to be done on the identification of villages that are included in the elements of nationalism village. This becomes important and serves as a basis for reference to the grouping of villages that have an element of pluralism and will later be designated as a nationality village. On the other hand can be used as a reference and input by local governments in providing policies regarding the existence of a nationality village. Besides that, support from the local government related to the promotion of the potential / superiority of culture, ethnicity, villages and regions in Banyuwangi is very intensively carried out, as evidenced by the many festivals that are held and scheduled every one year. This research is to identify villages that have the potential to become nationality villages in which there are various criteria or elements that have been fulfilled, one of which is the composition of religion, culture, ethnicity and the form of tolerance that is maintained and sustainability, from the results of its study can be used as foothold for policy makers, especially the Banyuwangi local government and related ministries. This research uses a qualitative approach with a case study design and uses a phenomenological perspective. The selection of respondents using snowball sampling, namely the village and district government in Blimbingsari, community leaders, religious leaders, Banyuwangi National Mixing Forum and cultural figures. From the results of the research it can be seen that the tolerance value of patoman society and its diversity is very close and very good in community relations can be seen from the implementation of mutual values and religious tolerance.
\end{abstract}

Keywords: Identification, village, patoman nationality

\begin{abstract}
ABSTRAK
Identifikasi munculnya desa kebangsaan di desa Patoman perlu dilakukan, hal ini dilakukan karena desa Patoman memiliki potensi berbagai jenis masyarakat yang heterogen dari segi agama, budaya maupun etnis. Sehingga perlu ditelusuri dan perlu
\end{abstract}


dilakukan studi lanjut mengenai identifikasi desa-desa yang termasuk ke dalam unsur desa kebangsaan. Hal ini menjadi penting serta sebagai dasar rujukan pengelompokan desa-desa yang memiliki unsur pluralisme dan nantinya ditetapkan sebagai desa kebangsaan. Di sisi lain dapat dijadikan sebagai rujukan dan masukan oleh pemerintah daerah dalam memberikan kebijakan mengenai adanya desa kebangsaan. Di samping itu dukungan dari pemerintah daerah setempat berkaitan dengan promosi tentang potensi/keunggulan budaya, etnik, desa maupun wilayah di Banyuwangi sangat gencar dilakukan, terbukti dengan banyaknya festival-festival yang diselenggarakan serta dijadwalkan tiap satu tahunan. Penelitian ini untuk mengidentifikasi desa-desa yang berpotensi menjadi desa kebangsaan yang di dalamnya terdapat berbagai kriteria-kriteria atau unsur yang telah terpenuhi salah satunya adalah komposisi agama, budaya, etnis maupun wujud adanya toleransi yang tetap terjaga serta keberlanjutan, dari hasil kajiannya dapat digunakan sebagai pijakan bagi para pemangku kebijakan khususnya pemerintah daerah Banyuwangi maupun kementrian terkait. Penelitian ini menggunakan pendekatan kualitatif dengan rancangan studi kasus serta memakai perspektif fenomenologis. Pemilihan responden dengan menggunakan snowball sampling, yaitu pihak Pemerintahan desa dan kecamatan di Blimbingsari, tokoh masyarakat, pemuka agama, Forum Pembauran Kebangsaan Banyuwangi serta budayawan. Dari hasil penelitian terlihat bahwa nilai toleransi masyarakat Patoman dengan kemajemukanya sangat erat dan baik sekali dalam hubungan bermasyarakat terlihat dari pelaksanaan nilai-nilai gotong-royong dan toleransi agama.

Kata kunci: Identifikasi, desa, kebangsaan patoman

\section{PENDAHULUAN}

Indonesia memiliki corak dan karakteristik masyarakat yang homogen dan menyebar ke seluruh penjuru nusantara. Sejatinya tiap individu memiliki pandangan yang sama yakni wawasan nusantara. Berdasarkan Ketetapan MPR Tahun 1993 dan 1998 tentang GBHN Wawasan Nusantara yang merupakan wawasan nasional adalah cara pandang dan sikap bangsa Indonesia mengenai diri dan lingkungannya dengan mengutamakan persatuan dan kesatuan bangsa serta kesatuan wilayah dalam menyelenggarakan kehidupan bermasyarakat, berbangsa, dan bernegara untuk mencapai tujuan nasional. Dari pengertian tersebut, wawasan nusantara berperan penting dalam penyelenggaraan serta praktik berbangsa dan bernegara maupun mengenai urusan kerukunan serta toleransi dalam masyarakat Indonesia.

Penelitian terdahulu yang dilakukan oleh Darwis Muhdina (2015) meneliti tentang kerukunan umat beragama berbasis kearifan lokal di kota makasar, hasil penelitiannya adalah konsep kerukunan hidup umat beragama 
mencakup 3 kerukunan, yaitu: (1) kerukunan intern umat beragama; (2) kerukunan antarumat beragama; dan (3) kerukunan antarumat beragama dengan Pemerintah. Kearifan lokal tersebut memberi kontribusi besar terhadap terciptanya kerukunan umat beragama di Kota Makassar. Sedangkan penelitian Yusuf Hidayat (2013) yang meneliti tentang Hubungan Sosial Antara Etnis Banjar Dan Etnis Madura Di Kota Banjarmasin, hasil penelitian menyebutkan bahwa: Pertama, agama dan aktivitas ritual merupakan media integrasi bagi etnis Banjar dan Madura. Kedua, penegakan hukum dalam masyarakat telah menimbulkan rasa hormat masyarakat terhadap hak orang lain. Ketiga, sikap etnis Madura yang menghormati budaya lokal menumbuhkan pemahaman yang baik pada masyarakat etnis Madura terhadap etnis Banjar. Dari hasil penelitian terdahulu dapat disimpulkan bahwa kerukunan yang terjalin di masyarakat berpijak pada sikap toleransi serta tingginya sikap integrasi. Oleh karena itu nasionalisme, atau semangat kebangsaan, merupakan suatu proyek bersama yang senantiasa harus diperjuangkan.

Kabupaten Banyuwangi merupakan salah satu Kabupaten di Jawa Timur yang memiliki penduduk asli dengan sebutan suku osing. Suku Osing pun sejatinya memiliki adat istiadat budaya dan bahasa yang berbeda dari suku Madura maupun Jawa. Letak geografis Banyuwangi juga mempengaruhi dari segi komposisi agama, suku, serta budaya. Dari faktor geografis itulah merupakan salah satu faktor pendorong terjadinya potensi keberagaman di banyuwangi yang khususnya pada wilayah desa. Kabupaten banyuwangi memiliki 25 kecamatan dan 217 desa. Pada seluruh wilayah tersebut banyak sekali terdapat potensi-potensi keanekaragaman agama, budaya maupun etnis. Disamping itu, peran dan dukungan pemerintah daerah setempat dalam mengembangkan potensi wilayah serta budaya lokal selalu dilakukan berkesinambungan baik ditingkat kabupaten, kecamatan, kelurahan dan pedesaan.

Pada kecamatan Blimbingsari terdapat 10 desa yang memiliki keanekaragaman agama, budaya maupun etnik namun masih belum terekspos. Desa yang seperti inilah sejatinya patut dilestarikan serta diberi penguatan oleh pemerintah daerah setempat agar ragam dan nilai toleransi tetap ada. Salah satu desa yang cukup terkenal yaitu Desa Patoman. Komposisi Desa Patoman sendiri memiliki karakteristik masyarakat yang heterogen dari segi agama, budaya, etnik serta masih terciptanya toleransi antar masyarakat. Berpijak dari hal tersebut 
peneliti ingin melakukan studi identifikasi desa-desa se-Kecamatan Blimbingsari dimana terdapat desa yang dapat memenuhi serta menampakkan unsur yang berkaitan dengan kebangsaan. Dengan kata lain desa yang didalamnya terdapat unsur kerukunan, toleransi tinggi serta jiwa semangat persatuan dan kesatuan. Serta tindak lanjut kedepannya adalah menjadikan desa yang memiliki potensi tersebut dengan sebutan desa kebangsaan.

\section{KAJIAN PUSTAKA}

\section{A. DESA}

Definisi desa menurut Undang-Undang No. 6 Tahun 2014, adalah kesatuan masyarakat hukum yang memiliki batas wilayah yang berwenang untuk mengatur dan mengurus urusan pemerintahan, kepentingan masyarakat setempat berdasarkan prakarsa masyarakat, hak asal-usul, dan atau hak tradisional yang diakui dan dihormati dalam sistem Pemerintahan NKRI. Kewenangan berdasarkan hak asal-usul adalah hak yang merupakan warisan yang masih hidup dan prakarsa desa atau prakarsa masyarakat desa sesuai dengan perkembangan kehidupan masyarakat.

Pemerintah desa adalah Kepala Desa atau yang biasa disebut dengan perangkat desa sebagai unsur penyelenggara Pemerintahan desa. Pemerintahan desa adalah penyelenggaraan urusan pemerintahan dan kepentingan masyarakat setempat dalam sistem pemerintahan Negara Kesatuan Republik Indonesia. Pemerintah desa berfungsi sebagai subsistem dari sistem administrasi pemerintahan di Indonesia, sehingga desa memiliki kewenangan, tugas dan kewajiban untuk mengatur dan mengelola kepentingan masyarakat mereka sendiri (Hehamahua, 2015).

Tipologi desa adalah merupakan fakta, karakteristik dan kondisi nyata yang khas keadaan terkini di desa maupun keadaan yang berubah berkembang dan diharapkan terjadi di masa depan (visi desa). Tipologi desa dibagi menjadi tiga yaitu Desa Tertinggal dan/atau sangat Tertinggal, Desa Berkembang, dan Desa Maju dan/atau Mandiri (Permendesa No. 22 Tahun 2016).

\section{B. NASIONALISME}

Dalam bahasa Inggris ada kata nation, national, nationalism. Dan dalam bahasa Belanda natie, national dan nationalisme. Bahasa Indonesia 
mengopernya dengan kata nasional dan nasionalisme yang berarti kebangsaan. Jadi nation atau natie dialih bahasakan dengan bangsa. Menurut Hans Kohn dalam karyanya yang berjudul "Nasionalisme, Arti dan Sejarahnya": "Nasionalisme adalah salah satu dari kekuatan yang menentukan dalam sejarah modern (Hutauruk, 1984:xvii). Nasionalisme adalah paham kebangsaan artinya bahwa suatu bangsa mempunyai perasaan cinta tanah air, cinta terhadap bangsa sendiri (Junanto, 2013:11). Nasionalisme dapat dikatakan juga sebagai sebuah situasi kejiwaan di mana kesetiaan seseorang secara total diabdikan langsung kepada negara bangsa atas nama sebuah bangsa (Rosyada, 2003:24).

Sedangkan menurut Mustari (2014:156) nasionalisme adalah cara berfikir, bersikap dan berbuat yang menunjukan kesetiaan, kepedulian, dan penghargaan yang tinggi terhadap bangsa, lingkungan, fisik, sosial, budaya, ekonomi dan politik bangsanya. Bangsa (nation) sendiri berarti sekumpulan manusia yang sama bahasanya, sama adat istiadatnya, sama asal usulnya, sama kebudayaannya, senasib sepenanggungan, dan tempat kediamannya (negaranya) pun sama.

Nasionalisme sendiri mengandung makna "suatu sikap mental di mana loyalitas tertinggi dari individu adalah untuk negara-bangsa"; atau "sikap politik dan sosial dari kelompok-kelompok suatu bangsa yang mempunyai kesamaan kebudayaan, bahasa, dan wilayah, serta kesamaan cita- cita dan tujuan, dan dengan demikian merasakan adanya kesetiaan yang mendalam terhadap bangsa. Unsur terpenting dalam nasionalisme menurut Hutauruk (1984:xvii) adalah:

1) Kesetiaan mutlak, kesetiaan tertinggi individu itu adalah pada nusa dan bangsa

2) Kesadaran akan suatu panggilan

3) Keyakinan akan suatu tugas dan tujuan yang harus dikejar

4) Harapan akan tercapainya sesuatu yang membahagiakan

5) Hak hidup, hak merdeka dan hak atas harta benda yang berhasil dikumpulkan dengan halal

6) Kepribadian kolektif yang mengandung perasaan mesra sekeluarga, nasib serta tanggung jawab yang sama, persaudaraan dan kesetiaan di antara manusia itu 
7) Jiwa rakyat (Volkgeist) yang dapat diselami dalam tradisi, bahasa, serita dan nyanyian rakyat

8) Toleransi yang sebesar-besarnya terhadap satu sama lain.

\section{HAKIKAT RASA KEBANGSAAN}

Pengertian bangsa menurut Hans Kohn (1955) adalah Hans Kohn Bangsa adalah buah hasil hidup manusia dalam sejarah. Suatu bangsa merupakan golongan yang beraneka ragam dan tidak bisa dirumuskan secara eksak. Bangsa itu terbentuk karena persamaan bahasa, ras, agama, peradaban, wilayah, Negara dan Kewarganegaraan. Suatu bangsa juga tumbuh, berkembang dan terbentuk melalui suatu proses sejarah. Terlepas dari kajian tentang nasionalisme dan definisi bangsa, yang tidak kalah penting adalah mengenai hakikat rasa kebangsaan. Jika nasionalisme diartikan secara sederhana sebagai suatu paham dengan rasa kebangsaan, maka selanjutnya harus diketahui pula hakikat dari rasa kebangsaan itu sendiri. Rasa kebangsaan bukanlah sesuatu yang unik milik bangsa Indonesia sendiri, sebab setiap bangsa juga memilikinya.

Menurut Yudohusodo (1996:12) memberikan definisi tentang rasa kebangsaan adalah :

Kesadaran berbangsa, yaitu kesadaran untuk bersatu sebagai suatu bangsa yang lahir secara alamiah karena sejarah, karena aspirasi perjuangan masa lampau, karena kebersamaan kepentingan, karena rasa senasib dan sepenanggungan dalam menghadapi masa lalu dan masa kini serta kesamaan pandangan, harapan dan tujuan dalam merumuskan cita-cita bangsa untuk waktu yang akan datang. Dengan kata lain, rasa kebangsaan itu adalah perekat yang mempersatukan dan memberikan dasar kepada jati diri kita sebagai bangsa. Sedangkan wawasan kebangsaan diungkapkan oleh Yudohusodo (1996:12) merupakan cara pandang yang dilingkupi oleh rasa kebangsaan, paham kebangsaan, dan semangat kebangsaan dalam upaya bangsa untuk mencapai cita-cita nasionalnya, dan mengembangkan eksistensi kehidupannya atas dasar nilai-nilai luhur bangsanya." Berdasarkan uraian di atas dapat disimpulkan bahwa hakikat rasa kebangsaan adalah kesadaran dari suatu bangsa untuk bersatu sebagai perekat yang mempersatukan dan memberikan dasar kepada jati diri sebagai bangsa.

Wawasan kebangsaan bukan hanya untuk dikaji, namun lebih penting untuk di aktualisasikan dalam kehidupan bermasyarakat. Menurut 
Yudohuso dkk (1994: 11) aktualisasi dari paham kebangsaan diwujudkan oleh perseorangan anggota masyarakat, oleh keluarga, oleh kelompok, oleh masyarakat, oleh pemerintah dan lembaga-lembaga negara. Aktualisasinya pada perseorangan berbentuk cara berpikirnya, cara merasakan sesuatu, reaksinya atas sesuatu hal, dan cara serta motifnya dalam melakukan sesuatu. Pada masyarakat berbentuk alasan dan sifat dari pengelompokanpengelompokan secara tindak-tanduk dari kelompok masyarakat itu. Pada pemerintah berbentuk program dan kebijakan-kebijakan yang dikeluarkan.

\section{STRUKTUR MASYARAKAT INDONESIA}

Struktur masyarakat Indonesia cenderung heterogen. Dalam masyarakat heterogen selalu memiliki karakteristik serta sifat yang Sebagai bangsa yang memiliki masyarakat majemuk Indonesia memiliki karakteristik yang dapat kita kenali dengan sebutan pluralistik, menurut Nasikun (2012) masyarakat majemuk memiliki karakteristik dan sifat dasar yaitu:

1. Terjadinya segmentasi ke dalam bentuk kelompok-kelompok yang seringkali memiliki kebudayaan/ sub kebudayaan yang berbeda satu sama lain.

2. Memiliki struktur sosial yang terbagi-bagi ke dalam lembaga-lembaga yang bersifat non komplementer.

3. Kurang mengembangkan konsensus di antara para anggota masyarakat tentang nilai- nilai sosial yang bersifat dasar Secara relative seringkali terjadi konflik di antara kelompok satu dengan yang lain.

4. Secara relatif integrasi sosial tumbuh di atas paksaan (coercion) dan saling ketergantungan di dalam bidang ekonomi.

5. Adanya dominasi politik oleh suatu kelompok atas kelompok lain.

\section{METODE PENELITIAN}

Penelitian ini menggunakan pendekatan kualitatif fenomenologis, karena sesuai dengan tujuan penelitian yaitu untuk mempelajari secara rinci fenomena sosial yang terjadi secara nyata dan apa adanya. Sejalan dengan hal itu deskripsi fenomenologis bisa dibedakan ke dalam tiga fase yaitu: (1) mengintuisi, (2) menganalisis, (3) menjabarkan secara fenomenologis. Dalam penelitian ini mengkaji lebih dalam terhadap desa-desa di kecamatan 
Blimbingsari tentang unsur-unsur yang terkait serta memenuhi sebagai desa kebangsaan. Setelah mendapatkan temuan-temuan dalam penelitian selanjutnya akan menggunakan teknik analisis data model analisis interaktif (interactive model of analysis) yang dikembangkan oleh Miles dan Huberman yaitu: (1) Reduksi data, (2) Penyajian data dan, (3) Penarikan kesimpulan / verifikasi.

\section{HASIL DAN PEMBAHASAN}

Nilai-nilai desa kebangsaan merupakan cermin dari pandangan hidup masyarakat Indonesia yang bersumber dari pancasila. Pancasila juga merupakan nilai harus di ikuti oleh hati nurani masyarakat Indonesia dengan dasar pada kepribadian bangsa. Nilai-nilai Pancasila menjadi pondasi yang diperlukan, serta motivasi untuk semua perbuatan baik dalam kehidupan sehari-hari dan negara. Dalam kehidupan bernegara, perwujudan nilai-nilai menjadi pedoman seluruh masyarakat.

Sebagai sebuah ideologi terbuka, Pancasila memungkinkan untuk mengakomodasi nilai-nilai yang terkandung dalam masyarakat seperti Ketuhanan, Kemanusiaan, Perserikatan, Keadilan, Kemasyarakatan, Keakraban, Keadilan, Kemasyarakatan. Nilai-nilai ini sesuatu yang digunakan dalam masyarakat Indonesia. Dengan menjadikan Pancasila sebagai ideologi terbuka, nilai-nilai ini mendapat perhatian khusus. Menurut saya, ini bukan kebetulan, melainkan bahwa Pancasila sebagai nasionalisme harus mengandung segala sesuatu yang merupakan keunikan masyarakat. Pancasila tidak mengimpor nilai-nilai dari luar ke dalam masyarakat Indonesia, tetapi meningkatkan nilai-nilai yang sudah ada di masyarakat dan menjadikannya sesuatu yang unik bagi Indonesia. Keindonesiaan kita, oleh karena itu, juga sangat kental karena nilai-nilai kebangsaan.

\section{A. NASIONALISME DAN KEBANGSAAN}

Penanaman dan penguatan kesadaran nasional tentang ideologi dan nilai-nilai Pancasila sangat penting karena kesadaran ini akan membentuk karakter dan memperkuat identitas bangsa Indonesia yang merdeka dan berdaulat. Meskipun pada level implementasi, sosialisasi nilai-nilai Pancasila mengalami pasang surut, namun sosialisasi Pancasila harus terus dilakukan untuk memperkuat moralitas masyarakat Indonesia. Dengan demikian, tanggung jawab terletak pada unsur bangsa untuk mengajarkan nilai-nilai Pancasila sebagai mandat untuk pembukaan UUD 1945 yang menekankan 
pentingnya mendidik kehidupan bangsa. Dalam hal ini, kecerdasan tidak hanya mencakup kaum intelektual, tetapi juga mencakup kecerdasan emosional, dan kecerdasan spiritual yang merupakan dasar bagi pengembangan kecerdasan nasional dalam bentuk kecerdasan ideologis. Masyarakat Patoman berpandangan bahwa sosialisasi nilai-nilai Pancasila telah berjalan sejauh ini; Namun, perlu ditingkatkan dengan memperluas jangkauan target sosialisasi dan tatap muka dengan orang-orang di tingkat yang lebih rendah, sehingga nilai-nilai toleransi di masyarakat Patoman yang memiliki multi agama dan budaya terlihat dan lebih tinggi. Majelis Permusyawaratan Rakyat Republik Indonesia dalam melaksanakan kegiatan ini harus melibatkan warga di tingkat desa di kabupaten Banyuwangi dengan sering adanya penyuluhan tentang nilai-nilai Pancasila yang tergabung dalam forum pembauran kebangsaan.

Mengenai target pemasyarakatan dalam kemajemukan, diperluas untuk memasukkan anggota masyarakat ke desa dan kecamatan dan dilakukan secara terbuka sehingga akan terbentuk desa-desa kebangsaan yang memiliki tingkat toleransi yang tinggi. Sedangkan metode yang digunakan adalah memanfaatkan petugas penyuluh pemasyarakatan ke tingkat masyarakat paling rendah seperti di desa. Kemudian dari sisi kelembagaan sehingga agenda pemasyarakatan dengan jujur terencana dan terstruktur hingga ke tingkat Kecamatan dan desa. Tujuannya adalah agar fasilitas pemasyarakatan tersebar secara merata dan menyebar ke tingkat masyarakat yang lebih luas. Masyarakat desa Patoman beranggapan bahwa sosialisasi nilai-nilai ini harus terus dilakukan dan terus dievaluasi sambil ditingkatkan, baik metode maupun teknis pelaksanaannya, penyelenggara dan bahannya. Hanya saja titik perbaikannya terutama pada target pemasyarakatan, yaitu masyarakat yang diperluas di semua komponen, disertai dengan penguatan dalam sistem kurikulum pendidikan di tingkat sekolah dasar dan menengah.

\section{B. SOSIAL BUDAYA DALAM PERBEDAAN (PLURAL)}

Setelah membahas tentang integrasi nilai Pancasila dalam masyarakat, selanjutnya adalah kita akan membahas mengenai penguatan harmoni sosial keagamaan dalam masyarakat plural. Harmoni yang dimaksud adalah sebuah kerukunan yang diciptakan oleh anggota di dalamnya dalam lingkungan masyarakat. Harmoni sosial juga merupakan gambaran masyarakat dinamis dan kreatif yang dapat diwujudkan dengan 
mengimplementasikan ajaran agama sebagai tindakan atau prilaku dari suatu masyarakat.

Kata lain dari harmoni adalah rukun yang berarti tenteram atau damai. Kegiatan-kegiatan sosial yang banyak berkembang dan berpengaruh agar menjadi sebuah upaya menciptakan kerukunan antar umat beragama. Terdapat tiga komponen dalam mewujudkan kondisi ideal dalam kehidupan beragama yaitu sikap saling mengakui dan menyadari pluralitas, adanya sikap saling menghormati (toleransi), dan adanya sikap saling bekerja sama (resiprokal). Seperti halnya kegiatan yang ada dan diadakan oleh masyarakat, komunitas, pemerintahan, dan kelompok kelompok lainnya.

Peran agama juga dapat membantu menciptakan kedamaian masyarakat. Pada hakikatnya semua agama mengajarkan kepada hal yang baik atau positif, tidak ada yang mengajarkan hal yang buruk atau negatif. Bahkan agama juga mengajarkan sikap pluralisme dan toleransi kepada umatnya. Orang yang beragama harus percaya bahwa agama yang ia itulah agama yang paling baik dan paling benar, dan orang lain juga dipersilahkan, bahkan dihargai, untuk percaya dan yakin bahwa agama yang dipeluknya adalah agama yang paling baik dan paling benar.

Ketika masyarakat terjun ke dalam ranah komunikasi dan interaksi antar masyarakat lain, ia harus bisa menyeimbangkan dan mempunyai tujuan. Bukan hanya sekedar tujuan personal, melainkan tujuan bersama. Maka dari itu, pengelolaan kerukunan atau harmoni sosial diarahkan pada penguatan hubungan sosial.

Hubungan sosial itulah yang dikelola dan dipelihara oleh masyarakat secara detail agar tetap stabil. Pandangan harmoni sosial keagamaan tidak lepas dari sebuah kerukunan umat beragama. Kerukunan umat beragama bukan berarti merelatifir agama-agama yang ada dengan melebur kepada satu totalitas (sinkretisme agama) dengan menjadikan agama-agama yang ada itu, sebagai mazhab dari agama totalitas itu, melainkan sebagai cara atau sarana untuk mempertemukan, mengatur hubungan luar antara orang yang tidak seagama atau antara golongan umat beragama dalam proses sosial kemasyarakatan.

Interaksi sesama manusia dapat diperoleh dari berbagai cara, tinggal bagaimana cara kita mengolahnya menjadi hubungan yang baik. Proses 
harmoni dan integrasi sosial akan terbentuk jika terdapat tiga hal yaitu, Pertama, pemahaman agama yang inklusif. Kedua, ketaatan pada hukum. Ketiga, memaafkan masa lalu, trust, dan ikatan antarwarga.

Karena untuk menciptakan sebuah kedamaian, dimulai dari usaha individu masing-masing dalam menimbulkan praktik pluralisme dan terbuka satu sama lain. Maksudnya adalah terciptanya sebuah kedamaian yang dimulai dari suatu usaha dari para individu yang saling terbuka satu sama lain. Sistem sosial atau masyarakat dapat melakukan segala kegiatan yang mereka minati dan gemari.

Salah satunya adalah kegiatan berdasarkan tujuan yang ingin diciptakan oleh masyarakat dan pemerintah yaitu kegiatan sosial keagamaan yang akan membangun aroma keharmonisan. Masyarakat menurut Parsons merupakan suatu struktur yang diatur oleh sistem, dan masing-masing komponen terintegrasi dengan fungsinya sendiri-sendiri. Semua berjalan seimbang dan pada dasarnya adalah baik. Konflik atau ketidakseimbangan terjadi karena ada komponen yang tidak berjalan semestinya.

Sedangkan fungsionalis melihat masyarakat dan lembaga-lembaga sosial sebagai suatu sistem yang seluruh bagiannya saling tergantung satu sama lain dan bekerja sama menciptakan keseimbangan.

\section{SIMPULAN}

Pemahaman publik tentang nilai-nilai Pancasila juga sejalan dengan perkembangan pengaruh negatif globalisasi dan juga penguatan nilai-nilai yang datang dari luar, yang secara langsung atau tidak langsung telah menyebabkan kelebihan sikap dan perilaku masyarakat yang menyimpang dari nilai-nilai Pancasila, jika tidak dengan segera memiliki potensi untuk meningkatkan kearifan nasional, maka dapat meningkatkan keakuratan dan potensi negara untuk meningkatkan keakuratan dan kearifan nasional. untuk penghancuran Negara Kesatuan Republik Indonesia akan sangat besar di tengah persaingan ketat dalam kompetisi nasional dan negara di dunia dalam upaya meningkatkan pemahaman masyarakat tentang nilai-nilai Pancasila melalui proses sosialisasi efektif dan berkelanjutan. 


\section{UCAPAN TERIMA KASIH}

Terima kasih kepada DRPM Ristekdikti yang telah memberikan pembiayaan dalam penelitian ini serta kepada Program Studi Pendidikan Kewarganegaraan dan pendidikan Sejarah Universitas PGRI Banyuwangi. serta masyarakat Kecamatan Blimbingsari Kabupaten Banyuwangi.

\section{DAFTAR PUSTAKA}

Hutauruk. 1984. Gelora Nasionalisme Indonesia. Jakarta: Erlangga

Kohn, Hans. 1955. Nasionalisme: arti dan sejarah. Terjemahan oleh Sumantri Mertodipuro.1984. Jakarta: Erlangga

Ketetapan MPR Tahun 1993 dan 1998 tentang GBHN Wawasan Nusantara

Mohamad Mustari. 2014. Nilai Karakter Refleksi Untuk Pendidikan. Jakarta: PT Raja Grafindo Persada

Nasikun. 2012. Sistem Sosial Indonesia. Jakarta : Rajawali Press

Republik Indonesia. 2014. Undang-Undang No. 6 Tahun 2014 Tentang Desa.Jakarta.

Republik Indonesia. 2016. Peraturan Menteri Desa, Pembangunan Daerah Tertinggal, dan Transmigrasi No. 22 Tentang Penetapan Prioritas Penggunaan Dana Desa Tahun 2017. Jakarta.

Rosyada dkk. 2003. Pendidikan Kewarganegaraan (Civic Education) Demokrasi, Hak Asasi Manusia dan Masyarakat Madani. Jakarta: Pustaka Nasional

Subar, Junanto. 2013. Civic Education. Surakarta: Fataba Press

Yudohusodo, Siswono dkk. 1994. Nasionalisme Indonesia Dalam Era Globalisasi. Yogyakarta:Yayasan Widya Patria.

Yudohusodo, Siswono. 1996. Semangat Baru Nasionalisme Indonesia . Jakarta: Yayasan Pembangunan Bangsa. 